\title{
The Dynamic Impact of Oil Price on Investor Sentiment in Tehran Stock Exchange: An Industry-Level Analysis
}

\section{Seyed Hasan Masoudi Alavi}

MA. Student, Department of Management and Accounting, Farabi Faculty, University of Tehran, Qom, Iran. (Email: Seyed.Alavi.Masou@ut.ac.ir)

\section{Mohammad Nadiri*}

*Corresponding Author, Assistant Prof., Department of Management and Accounting, Farabi Faculty, University of Tehran, Qom, Iran. (Email: M.nadiri@ut.ac.ir)

\section{Ali Reza Saranj}

Assistant Prof., Department of Management and Accounting, Farabi Faculty, University of Tehran, Qom, Iran. (Email: Alisaranj@ut.ac.ir)

Document Type: Original Article

Received: 2021/05/08
Accepted: 2021/08/17
2021, Vol. 5, No. 3. 38-57.

Published: 2021/10/05

\begin{abstract}
Investor sentiment is one of the non-fundamental factors that affect the financial markets, which itself is influenced by various factors, including oil price changes. This study aims to investigate the impact of oil price on investor sentiment in stock market industries in the Tehran Stock Exchange (TSE) using monthly data from April 2010 to June 2020. To investigate this issue, stock exchange industries were grouped into three categories: total industries, oilrelated industries, and non-oil industries, and the effect of oil prices on investor sentiments in these three groups was examined using the pooled mean group (PMG) technique. The PMG approach considers both the short- and long-run relation between series and provides reliable results in the context of dynamic heterogeneous panel models. The implementation of PMG in all three models shows the impact of oil prices on investor sentiment over both the short and long run. Findings suggest also that oil price has positive and significant in all three models in the long run and the oil price coefficient is higher in oil-related industries than non-oil-related industries. These results are the opposite of the
\end{abstract}


results obtained by similar studies, which can be due to the special features of countries, e.g. being oil exporters or oil importers.

Keywords: Investor Sentiment, Oil Price, PMG Method, Industry.

DOI: 10.30699/IJF.2021.285242.1231

Publisher: Iran Finance Association Copyright: author(s)

Type of License: Creative Commons License (CC-BY 4.0)

\section{Introduction}

Crude oil is a strategic resource in international trade and plays a central role in the global economy (Gong and Lin, 2017; He, 2020). This substance has both a commodity property and financial property (Du et al., 2016; Filis et al., 2011). Given the unique characteristics of crude oil, the existing literature has been focused not only on the factors that influence changes in the price of this commodity (Kaufmann, 2011; Yao, Zhang \& Ma, 2019), but also on the effect of oil price volatility on various markets and macroeconomic variables such as inflation, disposable income, consumption, savings, investment, and expectations about current and future economic conditions (Wen et al., 2019; Ye et al., 2020).

With recent developments in the theories of behavioral finance, investor sentiment has been introduced as a new concept in financial market research. Investor sentiment is one of the most important factors that influence investors' decisions, and there has been extensive research on investor sentiment in financial markets as well as its impact on oil and energy price changes (e.g., Du et al., 2016; Du \& Zhao, 2017; Ji et al., 2019; Qadan \& Nama, 2018; Shahzad et al., 2019; Yang et al., 2019; He, 2020).

The relationship between oil price and investor sentiment has been investigated from two perspectives. Initially, these studies were mainly focused on the impact of investor sentiment on oil prices, assuming that it affects oil prices through real economic factors and speculation and is a predictor of future macroeconomic conditions (e.g., Du \& Zhao, 2017; Qadan \& Nama, 2018). In recent years, however, some studies have investigated this nexus in financial markets to find whether oil prices affect investor sentiment (e.g., Apergis, Cooray \& Rehman, 2018; Ding, Liu, Zhang \& Long, 2017, He, 2020). The basic idea is that oil market fluctuations are transmitted to the economic and financial system, thus influencing investor sentiment and decisions (He, 2020).

Like other oil-exporting countries, the Iranian economy as well as its 
capital market is directly and indirectly affected by oil price changes and shocks (Zaroki et al., 2018). The purpose of the present research is to investigate the impact of oil price changes on investor sentiment in the Tehran Stock Exchange (TSE). Accordingly, stock market sectors are divided into two groups: oil-related industries such as petrochemical and refining industries that are directly affected by oil price shocks, and non-oil-related industries such as financial intermediation and pharmaceutical industries that are not directly affected by these shocks. This study contributes to the literature in several ways. First, limited studies in this area have been almost entirely focused on the effect of oil price changes on investor sentiment in the United States and China, and to our knowledge, no study has investigated this relationship in the stock market of developing countries, especially oil exporters. Secondly, unlike the extant literature, we explore oil price changes and investor sentiment at the industry level. Thirdly, the estimation technique adopted in this paper is the PMG (pooled mean group) technique which is suitable to estimate dynamic heterogeneous panels, as well as with respect to other usual panel methods such as the GMM method used to estimate dynamic models, the PMG

approach considers both the short- and long-run relation between series (Pesaran et al. 1999).

The remainder of this paper is structured in several sections. Following the introduction, Section 2 provides the theoretical framework and the literature review, Section 3 outlines the research methodology, Section 4 presents the estimation results, and Section 5 provides the discussion and conclusions.

\section{Research Background}

Changes in oil prices play a crucial role in the economic conditions of different countries, especially major oil-producing countries and petroleum-exporting countries. Meanwhile, today, due to the growing trend of financialization in the commodity markets and the flow of capital to future commodity indices, oil has emerged as an important financial instrument and the changes in its price have attracted much attention (Ji and Zhang, 2019; Zhang, 2017). Several studies have been conducted on the effects of oil prices. Some studies have examined the factors affecting changes in oil prices, and other studies have examined the effects of oil prices on the macroeconomic variables in different countries and markets, such as the stock market. Various domestic and foreign studies have examined the effects of oil prices on the total capital market (Fang \& You, 2014; Wang, Wu \& Yang, 2013; Abonori \& Ziaodin, 2020) as well as various stock market industries (Kumar, 2017; Mamipour \& Feli, 2017; Salisu, 
Raheem, \& Ndako, 2019) or stock market companies (Malik \& Ewing, 2009).

By the development of behavioral finance theories and attention to the role of psychological and emotional factors, they have found a special role in the analysis of financial markets. In traditional asset pricing models, usually have no role for psychological factors and investor sentiment, but the results of recent studies show that, contrary to the classical financial theory, sentiment affects the prices of the stock. Behavioral finance theories indicate that investors' sentiment or mental state influences their decisions (Blajer et al., 2018; Lucey \& Dowling, 2005). Stambaugh et al. (2012) believe that investors' sentiment is a key factor in explaining stock pricing anomalies. Behavioral financial theories and the results of studies on the influence of investors' sentiment on financial markets have questioned the validity of the efficient markets hypothesis (Baker and Wurgler, 2007). Thaler et al. (1991) define market sentiment as a part of investors' expectations of asset return which is not warranted by economic principles. Baker and Wurgler (2006) define investor sentiment as an investor's optimism/pessimism about stock market index futures. In recent years, numerous domestic and foreign studies have been conducted on the impact of investors' sentiment on the stock market. They have mainly focused on the impact of investor sentiment on stock returns (Corredor et al., 2013; Frugier, 2016; Hosseini \& Morshedi, 2019), the effect of sentiment on stock return forecasting (Vozlyublennaia, 2014; Kim et al., 2014; Aissia, 2016), the effect of sentiment on stock market volatility (Kumari \& Mahakud, 2015), the relationship between investor sentiment and different types of stock markets (Baker and Wurgler, 2007; Kadilli, 2015; Liston, 2016) and the relationship between sentiment and the returns of different industries (Huang et al., 2014; Uygur \& Taş; 2014).

In the last decade, some studies have examined the effect of psychological and emotional factors on changes in oil prices, as well as the mutual effect of sentiment and oil prices, and this study addressed the effect of oil prices on investors' sentiment in the stock market.

First, previous studies mainly focused on the causal relationship between investor sentiment and crude oil prices. By using the Granger causality test, for example, Choi (2010) examined the causal relationship between investor sentiment and price changes in the NYMEX crude oil futures market from 1999 to 2009. Experimental results showed that prices greatly expressed the investors' sentiment in the market; however, it does not change prices. He and Casey (2015) showed that there is a Granger causality relationship between sentiment and changes in oil prices and stocks of oil service companies. By gradually identifying the causality between investors' sentiment and crude oil 
prices, some researchers have examined the role of investors' sentiment in crude oil price volatility (Ye et al., 2020). These studies show that investors' sentiment can explain or forecast the trends of oil prices. By creating a sentiment index for West Texas Intermediate (WTI) and Brent crude oil, Deeney et al. (2015) showed that crude oil futures prices can be determined under the influence of investor sentiment. Du et al (2016) used the quantile regression method and found that investor sentiment could explain the volatility in oil, gasoline, and stock prices of oil companies. Du, Gunderson, and Zhao (2016) showed that investors' sentiment in financial markets can influence the potential demand for oil and changes in oil prices. Du and Zhao (2017) showed the significant impact of sentiment on the unprecedented increase of oil prices from 2003 to 2008. Qadan \& Nama (2018) analyzed the relationship between investor sentiment and oil prices. And found the sentiment has significant effects on crude oil prices. They also showed that fluctuations in these emotional indicators could explain the volatility in oil prices.

A limited number of studies have examined the effect of oil price shocks on investor sentiment in the stock market (Ye et al., 2020). Even these studies have primarily examined the United States and China, and, to our knowledge, no study has investigated the effect of oil price shocks on investor sentiment in developing countries and major oil exporters.

Oil price shocks can significantly affect investor sentiment by affecting real economic activity and macroeconomic variables such as economic growth, inflation, and consumption since investor sentiment is sensitive to changes in macroeconomic conditions (He, 2020). Meanwhile, many studies have shown the significant effect of oil price fluctuations on stock market return (e.g., Bouri et al., 2017). Therefore, oil price shocks will inevitably affect investor sentiment in the stock market. Using a structural vector autoregression (SVAR) model, Ding et al. (2017) found that a $1 \%$ increase in crude oil price fluctuates negatively affects stock market sentiment by $3.94 \%$. Also, the average contagion delay of international crude oil price fluctuation on investor sentiment in the Chinese stock market is 8 months. Güntner and Linsbauer (2018) investigated the effect of structural supply and demand shocks on U.S. consumer confidence. They found that aggregate and precautionary oil demand shocks significantly affect consumer confidence. However, He and Zhou (2018) found that only oil-specific demand shocks affect investor sentiment in the U.S. He (2020) examined the nonlinear causality between investor sentiment and oil price in the Chinese stock market and found a significant nonlinear Granger causality running from oil price to Chinese investor 
sentiment.

Studies show that oil price shocks can influence decisions about production, consumption, investments, and other issues due to the commodity and financial attributes of oil (Xiao et al., 2018). Under these conditions, oil market fluctuations are inevitably transmitted to the economic and financial system and affect investors' decisions and, consequently, investor sentiment (He, 2020). Therefore, the literature indicates that oil price affects investor sentiment through two channels, i.e., real economic factors and the stock market (He, 2020). However, it must be noted that the impact of oil shocks varies between oil-importing and oil-exporting countries. In oil-exporting countries, oil price shocks can have a significant impact on the macroeconomic condition and real economic activity by affecting the general level of prices (Ratti \& Vespignani, 2016; Sodeyfi \& Katircioglu, 2016).

In oil-exporting countries, oil shocks affect real economic variables mainly through the GDP channel. Changes in oil prices in exporting countries increase their revenues, thus affecting the demand for goods and financial assets since oil prices and related shocks can affect stock returns and/or stock prices through expected revenue from future cash flows (Wang et al., 2013). Different stock market industries and sectors of the economy also respond differently to oil shocks depending on whether oil and its derivatives are inputs or outputs for that industry or sector. In companies where oil is output, an increase in oil prices leads to an increase in cash flows, while in companies where oil is a key input, cash flows can decrease (Abu-Nuri \& Ziauddin, 2020).

Macroeconomic conditions also have a significant effect on investor confidence and sentiment toward economic activities. For example, higher oil prices usually lead to a stressful macroeconomic environment, strong inflationary expectations, and higher interest rates in oil-importing countries, which negatively affect investor sentiment (Apergis et al., 2018). Conversely, higher oil prices increase positive investor sentiment in oil-exporting countries. Moreover, as noted earlier, there is ample evidence that fluctuations in crude oil prices have a major impact on the stock market and its various industries. The performance of stock markets and various industries is an important factor that influences investors' decisions and inevitably affects investor sentiment. As the impact of oil price shocks on the stock market increases, the impact of the stock market on investor sentiment is strengthened. Oil prices have a second-round effect on investor sentiment (He et al., 2019).

Given the above arguments, understanding the dynamics of crude oil fluctuations, stock market, and various stock market industries and how it 
influences investor sentiment is very important. Investors need to know how oil price fluctuations affect the stock market and identify industries that are affected more quickly and more frequently by these fluctuations. On the other hand, examining the effects of oil prices on investor sentiment provides new insights into the drivers of investor confidence which is an important indicator of future economic conditions. In addition, understanding how oil prices affect investor sentiment provides useful information for investors' risk management and hedging strategies as well as implications for policymakers to generate more accurate forecasts and help minimize potential business cycle fluctuations.

Therefore, the present research tests the following two hypotheses:

H1. There is a significant positive relationship between oil prices and investor sentiment in different industries in the Tehran Stock Exchange.

H2. The effect of oil prices on investor sentiment is significantly different in oil-related industries than in non-oil-related industries.

\section{Methodology}

\section{Econometric Model and Method of Research}

In this research, the econometric method of the "Pooled Mean Group" (PMG) estimator is used to investigate both research hypotheses, the model of which is as follows:

$$
\begin{aligned}
\text { Sentiment }_{i t}= & \sum_{j=1}^{p} \theta_{i j} \text { Sentim }_{i . t-j}+\sum_{j=1}^{n} \beta_{i j} O P_{i . t-j}+\sum_{j=1}^{n} \beta_{i j} C P I_{i . t-j} \\
& +\sum_{j=1}^{n} \beta_{i j} C U R R_{i . t-j} \sum_{j=1}^{n} \beta_{i j} L I Q_{i . t-j}+\sum_{j=1}^{n} \beta_{i j} I_{N T E R B_{i . t-j}} \\
& +\sum_{j=1}^{n} \beta_{i j} G D P R_{i . t-j}+\mu_{i}+\varepsilon_{t}
\end{aligned}
$$

To test the research hypotheses, this model will be tested separately for the three groups of the whole industries, the industries with a direct relationship with oil, and the industries without any direct relationship with oil. To eliminate the bias caused by heterogeneous slopes in dynamic panel models such as the Generalized Method of Moments (GMM) with a long time horizon, Pesaran and Smith (1995) and Pesaran, Shin, and Smith (1999) presented two 
estimators: the Mean Group (MG) and the Pooled Mean Group (PMG). The MG and PMG estimation methods are the applications of the ARDL models in the panel data, and just as the ARDL, they include lag(s) in the dependent variable, which can show the dynamics in the panel model. In the MG method, first, an ARDL model is estimated for each cross and then the mean of the estimated coefficient is calculated. With this estimator, the intercepts, slope coefficients, and variances can vary in all groups. In the PMG method, the intercepts, short-term coefficients, and residual variances can vary in the mean groups, but in this method, no restrictions are applied in the long-term coefficients so that they are the same across the groups (e.g. the fixed effects estimator). The MG and PMG methods with large enough lag also provide a super-consistent estimator for long-term parameters even when the regressors are I (1) (Pesaran, Shin, and Smith, 1999). To choose between the two estimators, MG and PMG, the Hausman test is used, the null hypothesis of which is the use of the PMG method and its alternative hypothesis is the use of the MG method.

\section{Research Variables}

In relation to (1), which is used to test the research hypotheses, the dependent variables SENTIMENT it denote the investors' sentiment in different industries and the independent variables $\mathrm{OIL}_{\mathrm{it}}$ denote the price of crude oil. Other variables included in the model are the control variables: $C_{U R R}$ it is the exchange rate (the exchange rate of Iranian Rial is equal to the US Dollar); $\mathrm{CPI}_{\text {it }}$ is the consumer price index which is an indicator of inflation; INTERB ${ }_{\text {it }}$ is the interbank interest rate, and GDPR ${ }_{\text {it }}$ denotes the real Gross Domestic Product (GDP). The oil variable has been extracted from the OPEC site the other macroeconomic variables have been derived from the central bank's time series and the economic indicators provided by the central bank.

The dependent variable of this research is the index of the investors' sentiment in various stock market industries. In different studies, two types of direct and indirect indicators are used to measure sentiment (Baker and Wurgler, 2006). Since the direct indicator of sentiment is not calculated by the relevant financial institutions in Iran, the indirect indicators should be used in this regard. In their studies, Baker and Wurgler $(2006,2007)$ and Baker et al. (2012) used some variables to calculate the total market sentiment index. In this study, considering that the research is conducted at the industry level, using four Proxy of the volume Trades, the value of Trades, the number of new investor accounts, and the number of Trades monthly, the sentiment index was extracted by the use of the Principal Component Analysis (PCA) method, the 
first main component of which has been used as an indicator of sentiments in this study. One of the advantages of the PCA method is indexing and combining variables that have high multicollinearity with each other.

\section{Statistical Population and Sample}

The statistical population of this research on the industries existing in the Iranian stock market, which, according to the data from the Rahavard Novin Database ${ }^{1}$, includes 43 listed industries, consists of 24 important stock exchange industries. These industries were divided in terms of their direct relationship with oil and lack of their direct relationship with oil prices. The criteria for the relationship and the lack of relationship are based on the raw materials and inputs used, the fuel costs, and the scope of joint activities among the industries, according to which 9 industries were selected: chemical, oil products, rubber, and plastic, cement, base metals, lime and gypsum, coal mining, and multidisciplinary industrial, Extraction of Oil, Gas and Ancillary Services Except Exploration and mining. 15 industries were also considered as the industries with a little or less direct relationship, including automobiles, Banks \& Monetary Financial Institutions, pharmaceuticals, Building Construction \& Mass Housing, Engineering And Technical, machinery and equipment, computers, electrical devices, financial and monetary intermediation, warehousing and communications, non-metallic minerals, metal products, mining other mines, telecommunications, insurance, and pensions.

\section{Research findings}

\section{Descriptive Statistics}

Table 1. Descriptive statistics

\begin{tabular}{|c|c|c|c|c|c|c|}
\hline Descriptive statistics & SENTIMENT & OIL & CURR & CPI & INTERB & GDPR \\
\hline Avg & $-9.37 \mathrm{E}-17$ & 75.513 & 49385.05 & 94.19163 & 20.07 & 1561956 \\
\hline Median & -0.41395 & 71.72 & 34664 & 90.15 & 19.48 & 1532321 \\
\hline Maximum & 27.20865 & 122.49 & 212676 & 214.16 & 28.8 & 1903916 \\
\hline Minimum & -0.52567 & 19.9 & 10044 & 31.61 & 9 & 1408795 \\
\hline Std. dev & 1.58587 & 26.818 & 43672.9 & 46.51554 & 4.275 & 111687 \\
\hline Skewness & 7.865217 & 0.018 & 1.597 & 0.806 & 0.079 & 0.801 \\
\hline Kurtosis & 87.6471 & 1.727 & 4.56 & 2.999 & 2.84 & 2.918 \\
\hline Observations & 2952 & 2952 & 2952 & 2952 & 2952 & 2952 \\
\hline
\end{tabular}

\footnotetext{
${ }^{1}$ Rahavard is the largest financial and trading database of companies listed on the Iranian Stock Exchange and OTC.
} 
Table 1 reports the descriptive statistics of the model variables. The mean price of crude oil in this period is about 75\$, which in March 2011 with the increase in world oil prices reaches its maximum price of $122.5 \$$.

\section{Correlation between Variables}

Table 2. Matrix correlation

\begin{tabular}{|c|c|c|c|c|c|}
\hline Variables & OIL & CURR & CPI & INTERB & GDPR \\
\hline OIL & 1 & & & & \\
\hline CURR & -0.41513 & 1 & & & \\
\hline CPI & -0.59936 & 0.927828 & 1 & & \\
\hline INTERB & 0.053104 & -0.12993 & 0.002979 & 1 & \\
\hline GDPR & -0.21752 & 0.024848 & 0.120123 & -0.21242 & 1 \\
\hline
\end{tabular}

Table 2 presents the correlations between the research variables. As can be seen, there is a little correlation between variables, except for the exchange rate (CURR) and the CPI, which have a relatively high correlation and there is a possibility of multicollinearity between them. One way to solve the problem is dropping one of the collinear variables. But due to the importance of both variables, we estimated the models with two variables separately, and then the model was estimated with both variables together. The estimation results were not different significantly from each other so we use both variables in the models without worrying about the multicollinearity problem. Meanwhile, it is often said multicollinearity problem is more of a problem with the data than with the model so increasing the sample size and estimating the model with methods like panel data, can reduce and solve the multicollinearity problem (Brooks, 2019).

\section{Investigating the stationary of Variables and Model Cointegration}

In the time-series data and the panel data, which is a combination of the time series and the cross-sectional data, to avoid the problem of spurious regression, it is necessary to examine the problem of stationary and cointegration of the variables. In the panel data analysis, several methods are used to examine the stationary of the variables, the most important of which is the Levin, Lin, and Chu's (2002) test. Levin, Lin, and Chu (LLC) showed that in the panel data analysis, the use of the unit root test for whole data has more power than the use of it for each cross separately. This test is a combination of the ADF test with the trend, which has high power in the case of the heterogeneity of crosses and heteroscedasticity of the residuals. Table 3 presents the stationary of the variables using the LLC method, indicating the non-stationary of some variables in the level and the stationary of the others with a first-order difference so we can use the PMG method for estimation. 
Iranian Journal of Finance, 2021, Vol. 5, No. 3 (Masoudi Alavi, H.)

Table 3. Results of the panel stationary test (LLC method)

\begin{tabular}{|l|l|c|}
\hline \multicolumn{1}{|c|}{ Variables } & \multicolumn{1}{|c|}{ t-statistics } & Level or First-difference \\
\hline SENTIMENT & $-6.031^{* * *}$ & $\mathrm{I}(1)$ \\
\hline OIL & $-3.865^{* * *}$ & $\mathrm{I}(0)$ \\
\hline CURR & $-9.295^{* * *}$ & $\mathrm{I}(1)$ \\
\hline CPI & $-3.645^{* * *}$ & $\mathrm{I}(1)$ \\
\hline INTERB & $-2.065^{* *}$ & $\mathrm{I}(0)$ \\
\hline GDPR & $-2.419^{* * *}$ & $\mathrm{I}(0)$ \\
\hline
\end{tabular}

$* * *, * *$ and $*$ indicate statistical significance respectively at $1 \%, 5 \%$ and $10 \%$ level.

The cointegration test is used to investigate the long-run relationships between the model variables. In the panel models, methods such as Kao or Pedroni's methods are used to examine the cointegration between the variables. In this research, Pedroni's (2004) method is used to investigate the cointegration in the tested models. This method allows the existence of heterogeneity in the intercept and the slope of the cointegration equation. Pedroni's cointegration test uses the residuals of long-term regression estimation and its general equation is defined as follows:

$Y_{i t}=\alpha_{i}+\theta_{i} t+\beta_{1} X_{1 t}+\beta_{2} X_{2 t}+\cdots+\beta_{m i} X_{m i t}+\varepsilon_{i t}$

Where $i$ represents the cross, $t$ denotes the time period, and $m$ refers to the number of explanatory variables. The variables $\alpha_{i}$ and $\theta_{i}$ make it possible to study the fixed effects of the section as well as deterministic trends. $\varepsilon_{i t}$ denotes the estimated residuals of the long-term relationships (Pedroni, 2004).

Table 4. Pedroni's cointegration test

\begin{tabular}{|c|c|c|c|c|c|c|c|}
\hline \multicolumn{5}{|c|}{ Within-dimension (panel) } & \multicolumn{3}{|c|}{ Between-dimension (group) } \\
\hline $\begin{array}{c}\text { Model } \\
\quad \mathrm{S}\end{array}$ & $\begin{array}{c}\mathrm{V}- \\
\text { Statistic }\end{array}$ & $\begin{array}{c}\rho- \\
\text { Statistic }\end{array}$ & $\begin{array}{c}\text { PP- } \\
\text { Statistic }\end{array}$ & $\begin{array}{c}\text { ADF- } \\
\text { Statistic }\end{array}$ & $\begin{array}{c}\rho- \\
\text { Statistic }\end{array}$ & $\begin{array}{c}\text { PP- } \\
\text { Statistic }\end{array}$ & $\begin{array}{c}\text { ADF- } \\
\text { Statisti } \\
\text { c }\end{array}$ \\
\hline 1 & $7.222 * * *$ & $21.348 * * *$ & $\begin{array}{c}- \\
17.713 * * *\end{array}$ & $\begin{array}{c}- \\
6.563 * * \\
*\end{array}$ & $\begin{array}{c}- \\
17.205 * * \\
*\end{array}$ & $\begin{array}{c}15.463 * * * \\
-\end{array}$ & -0.572 \\
\hline 2 & $1.727 * *$ & $\begin{array}{c}12.773 * * * \\
-\end{array}$ & $\begin{array}{c}11.151^{* * * *} \\
-\end{array}$ & 0.764 & $\begin{array}{c}- \\
14.559 * * \\
*\end{array}$ & $\begin{array}{c}13.494 * * * \\
-\end{array}$ & 0.371 \\
\hline 3 & $\begin{array}{c}10.462 * * \\
*\end{array}$ & $\begin{array}{c}24.114 * * * \\
-\end{array}$ & $\begin{array}{c}16.534 * * * \\
-\end{array}$ & $\begin{array}{c}- \\
9.378^{* *} \\
*\end{array}$ & $\begin{array}{c}- \\
14.004 * * \\
*\end{array}$ & $\begin{array}{c}11.098 * * * \\
-\end{array}$ & -0.275 \\
\hline
\end{tabular}

$* * *, * *$ and $*$ indicate statistical significance respectively at $1 \%, 5 \%$ and $10 \%$ level. 
Table 4 reports the results of Pedroni's cointegration test between the tested variables in the three estimated models, i.e. the model estimations with the whole industries (Model 1), with the industries with a direct relationship with oil (Model 2), and with the industries without any direct relationship with oil (Model 3). Since in all three estimated models, the probability level is higher than 0.05 percent, the hypothesis of cointegration between the model variables is proved.

Also, in estimation with the Panel-ARDL method, as mentioned above, we must choose which estimating method (MG or PMG) is the appropriate method. According to the Hausman test we performed in all three models, the p-value of the Hausman test was higher than 0.05 percent so PMG is a more suitable method for estimating the models.

\section{Results of Model Estimation in Long-term and Short-term}

The results of the model estimations in the long-term for the three different groups, i.e. the whole industries, the oil-related industries, and the oil-unrelated industries are reported in Table 5 and the results of the model estimations in the short term are presented in Table 6.

Table 5. PMG long-run estimates

\begin{tabular}{|c|c|c|c|c|c|c|}
\hline \multirow{2}{*}{ variables } & \multicolumn{2}{|c|}{$\begin{array}{c}\text { Model 1 } \\
\text { (Whole industries) }\end{array}$} & \multicolumn{2}{c|}{$\begin{array}{c}\text { Model 2 } \\
\text { (Oil-related industries) }\end{array}$} & \multicolumn{2}{c|}{$\begin{array}{c}\text { Model 3 } \\
\text { (Oil-unrelated industries) }\end{array}$} \\
\cline { 2 - 7 } & coefficient & t-Statistic & coefficient & t-Statistic & coefficient & t-Statistic \\
\hline OIL & 0.0503 & $3.665 * *$ & 0.019 & $3.329 * * *$ & 0.00593 & $6.1103 * * *$ \\
\hline CURR & $-1.82 \mathrm{E}-05$ & -0.552 & $-2.02 \mathrm{E}-05$ & -0.871 & $1.63 \mathrm{E}-05$ & $5.4929 * * *$ \\
\hline CPI & 0.1269 & $3.595 * *$ & 0.062 & $3.592 * * *$ & 0.021496 & $9.19908 * * *$ \\
\hline INTERB & -0.721 & $-4.346 * *$ & -0.278 & $-5.394 * * *$ & -0.070498 & $-11.192 * * *$ \\
\hline GDPR & $-2.21 \mathrm{E}-05$ & $-4.282 * *$ & $-8.88 \mathrm{E}-06$ & $-4.734 * * *$ & $-2.00 \mathrm{E}-06$ & $-8.9404 * * *$ \\
\hline
\end{tabular}

$* * *, * *$ and $*$ indicate statistical significance respectively at $1 \%, 5 \%$ and $10 \%$ level.

As the results of the long-term relationships in Table 5 show, in all three estimated groups, there is a positive and significant relationship between the oil prices and the investors' sentiments, and the effect of oil prices on investors' sentiments in the period under review was significant at the level of 0.05 percent. According to the results, the effect of oil on sentiments in the second model, i.e. the industries with a direct relationship with oil, is about 0.019 , which is much higher than the effect of oil on the industries in the third model (about 0.006), i.e. the industries without a direct relationship with oil. Also, the second research hypothesis that the effects of oil prices on the investors' 
sentiment in the oil-related industry are different from the effects of oil prices in the industries without a direct relationship with oil is proved. Among the other variables, there is a positive and significant relationship between the inflation index and the sentiments as well as between the whole industries and different groups of industries. The results obtained regarding the relationship between the oil prices and sentiments are the opposite of the results obtained from the studies conducted by Apergis et al. (2018) and Qadan and Nama (2018) in the United States, and by He, et al. (2019), Ye et al. (2020), and He (2020) in China, and the reason for this should be considered in the economic characteristics of the countries, including being oil exporters or importers as well as the Pricing methods and selling of oil and oil products to various industries in the countries.

Table 6. PMG short-run estimates

\begin{tabular}{|c|c|c|c|c|c|c|}
\hline \multirow[t]{2}{*}{ variables } & \multicolumn{2}{|c|}{$\begin{array}{c}\text { Model } 1 \\
\text { (Whole industries) }\end{array}$} & \multicolumn{2}{|c|}{$\begin{array}{c}\text { Model } 2 \\
\text { (Oil-related } \\
\text { industries) }\end{array}$} & \multicolumn{2}{|c|}{$\begin{array}{c}\text { Model } 3 \\
\text { (Oil-unrelated } \\
\text { industries) }\end{array}$} \\
\hline & $\begin{array}{c}\text { coefficien } \\
t\end{array}$ & t-Statistic & $\begin{array}{c}\text { coefficien } \\
t\end{array}$ & $\begin{array}{c}\mathrm{t}- \\
\text { Statistic }\end{array}$ & $\begin{array}{c}\text { coefficien } \\
t\end{array}$ & t-Statistic \\
\hline $\operatorname{ECM}(-1)$ & -0.0581 & $-4.261 * * *$ & -0.202 & $\begin{array}{c}- \\
3.014 * * \\
*\end{array}$ & -0.019 & $-3.402 * * *$ \\
\hline $\begin{array}{c}\Delta \text { SENTIMENT }( \\
-1)\end{array}$ & -0.7269 & $\begin{array}{c}- \\
16.145^{* *} \\
*\end{array}$ & -0.640 & $\begin{array}{c}- \\
7.887 * * \\
*\end{array}$ & -0.7634 & $\begin{array}{c}- \\
14.063 * * \\
*\end{array}$ \\
\hline $\begin{array}{c}\Delta \text { SENTIMENT }( \\
-2)\end{array}$ & -0.5963 & $-9.228 * * *$ & -0.312 & $\begin{array}{c}- \\
2.529 * * \\
*\end{array}$ & -0.7524 & $\begin{array}{c}- \\
12.854 * * \\
*\end{array}$ \\
\hline $\begin{array}{c}\text { SENTIMENT( } \\
-3)\end{array}$ & -0.1525 & $-2.566 * * *$ & 0.050 & 0.553 & -0.2909 & $-4.186 * * *$ \\
\hline$\Delta(\mathrm{OIL})$ & -0.0078 & $-2.707 * * *$ & -0.010 & $\begin{array}{c}- \\
2.651 * * \\
*\end{array}$ & -0.0022 & -0.815 \\
\hline$\Delta \mathrm{OIL}(-1)$ & -0.0202 & $-4.210 * * *$ & -0.029 & $\begin{array}{c}- \\
2.972 * * \\
*\end{array}$ & -0.0193 & $-3.335 * * *$ \\
\hline$\Delta \mathrm{OIL}(-2)$ & 0.0009 & 0.329 & 0.0025 & 0.414 & -0.0047 & $-1.716^{*}$ \\
\hline$\Delta$ OIL(-3) & -0.0059 & $-2.420 * * *$ & -0.004 & -1.333 & - & - \\
\hline$\Delta$ CURR & $2.20 \mathrm{E}-05$ & $3.186 * * *$ & $3.90 \mathrm{E}-05$ & $\begin{array}{c}2.700 * * \\
*\end{array}$ & $1.41 \mathrm{E}-05$ & $-2.037 * *$ \\
\hline$\Delta$ CURR(-1) & 5.89E-07 & 0.132 & 9.49E-06 & 1.307 & $2.93 \mathrm{E}-06$ & 0.672 \\
\hline$\Delta$ CURR(-2) & $3.75 \mathrm{E}-05$ & $3.429 * * *$ & $3.82 \mathrm{E}-05$ & $\begin{array}{c}2.586 * * \\
*\end{array}$ & $3.37 \mathrm{E}-05$ & $2.448 * * *$ \\
\hline$\Delta$ CURR(-3) & $-1.10 \mathrm{E}-05$ & $-2.772 * * *$ & $-1.58 \mathrm{E}-05$ & $-1.884 *$ & - & - \\
\hline
\end{tabular}


The Dynamic Impact of Oil Price on Investor Sentiment in...

\begin{tabular}{|c|c|c|c|c|c|c|}
\hline $\mathrm{D}(\mathrm{CPI})$ & -0.0579 & $-2.035^{* *}$ & -0.062 & -1.096 & -0.0233 & -0.833 \\
\hline$\Delta$ CPI(-1) & -0.0104 & -0.491 & 0.005 & 0.126 & -0.0268 & -1.287 \\
\hline$\Delta \mathrm{CPI}(-2)$ & -0.0379 & $-1.668^{*}$ & -0.079 & $-2.052^{* *}$ & 0.0080 & 0.824 \\
\hline$\Delta$ CPI(-3) & 0.0308 & 1.040 & 0.065 & 0.994 & & \\
\hline$\Delta$ (INTERB) & 0.0001 & 0.020 & -0.004 & -0.289 & 0.0005 & 0.158 \\
\hline$\Delta$ INTERB(-1) & 0.0020 & 0.237 & 0.005 & 0.293 & $-9.52 \mathrm{E}-06$ & -0.0019 \\
\hline$\Delta$ INTERB(-2) & 0.0109 & 1.429 & 0.024 & $1.706 *$ & 0.0062 & 1.282 \\
\hline$\Delta$ INTERB(-3) & -0.0042 & -0.582 & -0.002 & -0.157 & - & - \\
\hline$\Delta$ (GDPR) & $-2.10 \mathrm{E}-07$ & -0.976 & $-3.14 \mathrm{E}-08$ & -0.053 & $-6.69 \mathrm{E}-08$ & -0.664 \\
\hline$\Delta$ GDPR(-1) & $2.05 \mathrm{E}-06$ & $4.045 * * *$ & $2.84 \mathrm{E}-06$ & $\begin{array}{c}2.725 * * \\
*\end{array}$ & $1.61 \mathrm{E}-06$ & $4.508^{* * *}$ \\
\hline$\Delta$ GDPR(-2) & $2.75 \mathrm{E}-08$ & 0.064 & $-1.83 \mathrm{E}-07$ & -0.290 & $4.22 \mathrm{E}-07$ & 1.311 \\
\hline$\Delta$ GDPR(-3) & $-2.12 \mathrm{E}-07$ & -0.953 & $-2.37 \mathrm{E}-07$ & -0.416 & - & - \\
\hline Intercept & 2.1447 & $4.272 * * *$ & 2.787 & $\begin{array}{c}3.006 * * \\
*\end{array}$ & 2.2462 & $3.421 * * *$ \\
\hline
\end{tabular}

$* * *, * *$ and $*$ indicate statistical significance respectively at $1 \%, 5 \%$ and $10 \%$ level.

Table 6 reports the relationship between "the oil prices and the other control variables" and the "investors' sentiments" in the short term in three separate models, i.e. the whole industries (Model 1), 9 industries directly related to oil (Model 2) and industries unrelated to oil (Model 3). Lags in these models are automatically selected based on the Akaike information criteria. In the short-term test, the main focus is on the Error Correction Model (ECM) coefficient, which shows the adjustment speed in the variable relationships between the short-term and the long-term. The ECM coefficient in the three estimated models is $-0.058,-0.20$, and $-0.019 \%$, respectively, indicating that in Model 1, in each period, the imbalance between the short-term and long-term relationships among the explanatory and dependent variables decreases by about 0.058 and the relationship between the variables moves towards a longterm relationship. As the results show, the adjustment speed in Model 2, i.e. the industries directly related to oil, is higher and faster than in the two other models.

\section{Conclusion and Suggestions}

In this article, we grouped Iranian stock market industries into three categories, whole industries, oil-related industries, and oil-unrelated industries, and examines the relationship between investor sentiment and oil prices in these three groups separately with the PMG method. The results showed that there is a relationship between the oil prices and the investor sentiment in all three estimated models in the short term and the long term. Based on the results, as expected, the effects of sentiment on the oil-related industries are greater than 
on those without a direct relation with oil. These results are the opposite of the results obtained by similar studies for the whole stock market like, Ye, et al, (2020); he, (2020); Apergis, et al. (2018), which can be due to the special features of countries, e.g. being oil exporters and oil importers and the way of pricing and selling oil and oil products to industries in countries. Since Iran is an exporter of oil and oil derivatives, and its economy is greatly affected by changes in oil prices and considering that the selling price of oil and oil products to industries is a fixed price, an increase in oil prices can benefit the capital market and the economy; in contrary, in some countries that are oil importers like China, such an increase leads to an increase in the costs of their industries, especially in the oil-related industries, which is considered as a negative shock affecting them. Also, the low depth of the Iranian stock market and its constraints, such as the ban of short selling and price limit, as well as the special conditions of the Iranian economy in the period under review, such as economic sanctions, may be possible causes of the difference in results.

The empirical results of this investigation have some important implications. First, this study shows that oil prices are an important factor that affects investor sentiment. Therefore, changes in oil prices should be taken into account when exploring the cause of investor sentiment. Moreover, this finding enables investors to make more effective decisions by using oil market information. In addition, considering that oil prices have significant long-run and short-run effects on investor sentiment, individual and institutional investors should focus more on this linkage and adjust their investment strategies over time and investors may benefit from these insights for hedging activities in the stock market industries. The effects of energy price changes on investor sentiment at the market and industry level, examining the two-way relationship between oil price and sentiment at the market level, investigating the relationship between oil shocks and sentiment at specific stock market industries such as petrochemical and refining industries, examining the linear and non-linear relationships of oil changes on investors sentiment, and studying the asymmetric relationship between the effects of oil price changes on investor sentiment and the stock market is bullish and bearish markets can be discussed in future research. Lack of calculation of sentiment index by the Securities and Exchange Organization and relevant financial institutions for Tehran stock exchange has been among the limitations in conducting this research because searcher himself must construct the index and some data to calculate the index are not available monthly over time.

Funding: This research received no external funding. 


\section{References}

Abounoori, E., Ziyaoddin, H. (2020). Return and Volatility of International Oil Price and Stock Index in OPEC Member Countries. Economic Modeling, 14(49), 1-24.

Aissia, D. B. (2016). Home and foreign investor sentiment and the stock returns. The Quarterly Review of Economics and Finance, 59, 71-77.

Apergis, N., Cooray, A., \& Rehman, M. U. (2018). Do energy prices affect US investor sentiment? Journal of Behavioral Finance, 19(2), 125-140.

Baker, M., \& Wurgler, J. (2006). Investor sentiment and the cross-section of stock returns. The journal of Finance, 61(4), 1645-1680.

Baker, M., \& Wurgler, J. (2007). Investor sentiment in the stock market. Journal of economic perspectives, 21(2), 129-152.

Baker, M., Wurgler, J., \& Yuan, Y. (2012). Global, local, and contagious investor sentiment. Journal of financial economics, 104(2), 272-287.

Blajer-Gołębiewska, A., Wach, D., \& Kos, M. (2018). Financial risk information avoidance. Economic research-Ekonomska istraživanja, 31(1), 521-536.

Bouri, E., Chen, Q., Lien, D., \& Lv, X. (2017). Causality between oil prices and the stock market in China: The relevance of the reformed oil product pricing mechanism. International Review of Economics \& Finance, 48, 34-48.

Brooks, c. (2019). Introductory econometrics for finance, 3rd Edition, Cambridge university press.

Choi, S. (2010). Does Investor's Sentiment Cause Market Prices? A case study of the NYMEX petroleum futures markets. Journal of International Finance and Economics, 10(4), 38-49.

Corredor, P., Ferrer, E., \& Santamaria, R. (2013). Investor sentiment effect in stock markets: Stock characteristics or country-specific factors?. International Review of Economics \& Finance, 27, 572-591.

Deeney, P., Cummins, M., Dowling, M., \& Bermingham, A. (2015). Sentiment in oil markets. International Review of Financial Analysis, 39, 179185.

Ding, Z., Liu, Z., Zhang, Y., \& Long, R. (2017). The contagion effect of international crude oil price fluctuations on Chinese stock market investor sentiment. Applied energy, 187, 27-36. 
Du, D., \& Zhao, X. (2017). Financial investor sentiment and the boom/bust in oil prices during 2003-2008. Review of Quantitative Finance and Accounting, 48(2), 331-361.

Du, D., Gunderson, R. J., \& Zhao, X. (2016). Investor sentiment and oil prices. Journal of Asset Management, 17(2), 73-88.

Fang, C. R., \& You, S. Y. (2014). The impact of oil price shocks on the large emerging countries' stock prices: Evidence from China, India and Russia. International Review of Economics \& Finance, 29, 330-338.

Filis, G., Degiannakis, S., \& Floros, C. (2011). Dynamic correlation between the stock market and oil prices: The case of oil-importing and oilexporting countries. International review of financial analysis, 20(3), 152-164.

Frugier, A. (2016). Returns, volatility and investor sentiment: Evidence from European stock markets. Research in International Business and Finance, $38,45-55$.

Gong, X., \& Lin, B. (2017). Forecasting the good and bad uncertainties of crude oil prices using a HAR framework. Energy Economics, 67, 315-327.

Güntner, J. H., \& Linsbauer, K. (2018). The effects of oil supply and demand shocks on US consumer Sentiment. Journal of Money, Credit and Banking, 50(7), 1617-1644.

He, L. T., \& Casey, K. M. (2015). The forecasting ability of the investor sentiment endurance index: the case of oil service stock returns and crude oil prices. Energy Economics, 47, 121-128.

He, Z. (2020). Dynamic impacts of crude oil price on Chinese investor sentiment: Nonlinear causality and time-varying effect. International Review of Economics \& Finance, 66, 131-153.

He, Z., \& Zhou, F. (2018). Time-varying and asymmetric effects of the oilspecific demand shock on investor sentiment. PloS one, 13(8), e0200734.

He, Z., He, L., \& Wen, F. (2019). Risk compensation and market returns: The role of investor sentiment in the stock market. Emerging Markets Finance and Trade, 55(3), 704-718.

Hosseini, Seyed Ali, Morshedi, Fatemeh. (2019), "the effects of investors' sentiment on the dynamics of trading on the Tehran stock exchange", Financial Accounting and Auditing Research, Year 11, No. 44, pp. 1-22.

Huang, C., Yang, X., Yang, X., \& Sheng, H. (2014). An empirical study of 
the effect of investor sentiment on returns of different industries. Mathematical Problems in Engineering, 2014.

Ji, Q., \& Zhang, D. (2019). How much does financial development contribute to renewable energy growth and upgrading of energy structure in China? Energy Policy, 128, 114-124.

Ji, Q., Li, J., \& Sun, X. (2019). Measuring the interdependence between investor sentiment and crude oil returns: New evidence from the CFTC's disaggregated reports. Finance Research Letters, 30, 420-425.

Kadilli, A. (2015). Predictability of stock returns of financial companies and the role of investor sentiment: A multi-country analysis. Journal of Financial Stability, 21, 26-45.

Kaufmann, R. K. (2011). The role of market fundamentals and speculation in recent price changes for crude oil. Energy Policy, 39(1), 105-115.

Kim, J. S., Ryu, D., \& Seo, S. W. (2014). Investor sentiment and return predictability of disagreement. Journal of Banking \& Finance, 42, 166-178.

Kumar, D. (2017). Realized volatility transmission from crude oil to equity sectors: A study with economic significance analysis. International Review of Economics \& Finance, 49, 149-167.

Kumari, J., \& Mahakud, J. (2015). Does investor sentiment predict asset volatility? Evidence from emerging stock market India. Journal of Behavioral and Experimental Finance, 8, 25-39.

Lee, C. M., Shleifer, A., \& Thaler, R. H. (1991). Investor sentiment and the closed-end fund puzzle. The journal of finance, 46(1), 75-109.

Levin, A., Lin, C. F., \& Chu, C. S. J. (2002). Unit root tests in panel data: asymptotic and finite-sample properties. Journal of econometrics, 108(1), 1-24.

Liston, D. P. (2016). Sin stock returns and investor sentiment. The Quarterly Review of Economics and Finance, 59, 63-70.

Lucey, B. M., \& Dowling, M. (2005). The role of feelings in investor decision-making. Journal of economic surveys, 19(2), 211-237.

Malik, F., \& Ewing, B. T. (2009). Volatility transmission between oil prices and equity sector returns. International Review of Financial Analysis, 3(18), 95-100.

Mamipour, S., \& Feli, A. (2017). The Impact of Oil Price Volatility on Tehran Stock Market at Sector-Level: A Variance Decomposition Approach. 
Monetary \& Financial Economics, 24(14), 205-236.

Pedroni, P. (2004). Panel cointegration: asymptotic and finite sample properties of pooled time series tests with an application to the PPP hypothesis. Econometric Theory, 597-625.

Pesaran, M. H., Shin, Y., \& Smith, R. P. (1999). Pooled mean group estimation of dynamic heterogeneous panels. Journal of the American Statistical Association, 94(446), 621-634.

Qadan, M., \& Nama, H. (2018). Investor sentiment and the price of oil. Energy Economics, 69, 42-58.

Ratti, R. A., \& Vespignani, J. L. (2016). Oil prices and global factor macroeconomic variables. Energy Economics, 59, 198-212.

Salisu, A. A., Raheem, I. D., \& Ndako, U. B. (2019). A sectoral analysis of asymmetric nexus between oil price and stock returns. International Review of Economics \& Finance, 61, 241-259.

Shahzad, S. J. H., Bouri, E., Raza, N., \& Roubaud, D. (2019). Asymmetric impacts of disaggregated oil price shocks on uncertainties and investor sentiment. Review of Quantitative Finance and Accounting, 52(3), 901-921.

Sodeyfi, S., \& Katircioglu, S. (2016). Interactions between business conditions, economic growth and crude oil prices. Economic ResearchEkonomska Istraživanja, 29(1), 980-990.

Stambaugh, R. F., Yu, J., \& Yuan, Y. (2012). The short of it: Investor sentiment and anomalies. Journal of Financial Economics, 104(2), 288-302.

Uygur, U., \& Taş, O. (2014). The impacts of investor sentiment on different economic sectors: Evidence from Istanbul Stock Exchange. Borsa Istanbul Review, 14(4), 236-241.

Vozlyublennaia, N. (2014). Investor attention, index performance, and return predictability. Journal of Banking \& Finance, 41, 17-35.

Wang, Y., Wu, C., \& Yang, L. (2013). Oil price shocks and stock market activities: Evidence from oil-importing and oil-exporting countries. Journal of Comparative Economics, 41(4), 1220-1239.

Wen, D., Wang, G. J., Ma, C., \& Wang, Y. (2019). Risk spillovers between oil and stock markets: A VAR for VaR analysis. Energy Economics, 80, 524535 .

Xiao, J., Zhou, M., Wen, F., \& Wen, F. (2018). Asymmetric impacts of oil 
price uncertainty on Chinese stock returns under different market conditions: Evidence from oil volatility index. Energy Economics, 74, 777-786.

Yang, C., Gong, X., \& Zhang, H. (2019). Volatility forecasting of crude oil futures: The role of investor sentiment and leverage effect. Resources Policy, 61, 548-563.

Ye, Z., Hu, C., He, L., Ouyang, G., \& Wen, F. (2020). The dynamic timefrequency relationship between international oil prices and investor sentiment in China: A wavelet coherence analysis. The Energy Journal, 41(5).

Yao, T., Zhang, Y. J., \& Ma, C. Q. (2017). How does investor attention affect international crude oil prices?. Applied Energy, 205, 336-344.

Zaroki, S., Motameni, M., Fathollahzadeh, A. (2018). The Effect of the Global Oil Price on Value of the Petrochemical Industry in Iran with NARDL Approach. Iranian Energy Economics, 7(27), 101-132.

Zhang, D. (2017). Oil shocks and stock markets revisited: Measuring connectedness from a global perspective. Energy Economics, 62, 323-333.

Bibliographic information of this paper for citing:

Masoudi Alavi, Seyed Hasan; Nadiri, Mohammad \& Saranj, Ali Reza (2021). The Dynamic Impact of Oil Price on Investor Sentiment in Tehran Stock Exchange: An Industry-Level Analysis. Iranian Journal of Finance, 5(3), 3857.

Copyright (C 2021, Seyed Hasan Masoudi Alavi, Mohammad Nadiri and Ali Reza Saranj 